\title{
The involvement of local communities in the conservation process of earthen architecture in the Sahel-Sahara region - the case of Djenné, Mali
}

\author{
Oussouby Sacko* (1)
}

\begin{abstract}
Recently, many cultural aspects of some African countries have been in danger of being lost due to cultural disruptions, nonadaptive construction techniques and a lack of adequate conservation systems and strategies. These include the well-known manuscripts of Timbuktu (Tombouctou) as well as architecture, languages, beads, textiles, costumes and other cultural objects. Immaterial heritage, such as oral history, traditional music, instruments and dance, is also affected.

In the northwestern part of Africa, the so-called Sahel-Sahara region, earthen architecture has played an important role in cultural identity and has been a key means of community establishment. This architectural heritage includes a wide variety of creations ranging from simple houses, granaries, and palaces to religious buildings, urban centres, cultural landscapes and archaeological sites. By studying northwestern African cultural heritage and cultural exchanges during trans-Saharan trade, we can benefit from traditional knowledge and use these teachings to build a sustainable knowledge system for earthen architecture conservation. This work is urgent since these structures are in danger of being lost, destroyed, badly conserved, or not documented.

The aim of this research is to point out, through an anthropological approach, the importance of local community involvement in the conservation process. This research is based on a comparative study of different earthen architecture conservation spaces within the abovementioned region that have been important and were influenced by cultural exchanges during trans-Saharan trade. In these historical towns, some architectural heritage sites have been abandoned and are in ruins, while others have been preserved solely as tourist attractions. In this paper, I introduce the case of Djenné to share our research approach. This paper provides insight into earthen architecture conservation issues and how local communities have used tangible and intangible methods to preserve cultural heritage.
\end{abstract}

Keywords: Earthen architecture, Tangible, Intangible, Djenné, Conservation, Mali

\section{Purpose}

In this paper, the complex relation between cultural conservation and cultural heritage preservation will be discussed based on observations of restoration projects

*Correspondence: osacko@kyoto-seika.ac.jp; oussoubysacko@gmail.com Graduate School of Architecture, Kyoto Seika University, 137 Kino-cho, Iwakura, Sakyo-ku, Kyoto 606-8588, Japan in Djenné. During the preservation process, some traditional techniques and know-how are revalorised and rehabilitated, while others are denied and lost. Additionally, preservation experts usually lead these projects in places where local masons are much more experienced. In this paper, I aim to point out the social issues raised by restoration projects and analyse multiple aspects of the relation and meaning of preservation. The field surveys were conducted between 2010 and 2017. Some 
information is based on surveys about the town and architecture conducted in Djenné between 2004 and 2010.

\section{Overview of Mali}

\subsection{Mali: history and geography}

Mali is a landlocked country situated in the heart of West Africa. It was a French colony for approximately one hundred years and used to be called French Sudan. It became independent on September 22, 1960. Mali is bordered on the north by Algeria, on the east by Niger and Burkina Faso, on the south by Côte d'Ivoire and Guinea, and on the west by Senegal and Mauritania. It is a relatively large country with an area of $1,240,192 \mathrm{~km}^{2}$, and the Sahara Desert covers $65 \%$ of its territory. (Fig. 1).

Mali has 4 World Cultural Heritage sites: Djenné (since 1988), Timbuktu (since 1988), and Tomb of Askia (since 2004) as cultural heritage sites and Cliff of Bandiagara
(Land of the Dogons) (since 1989) as a mixed cultural heritage site (UNESCO World Heritage Centre, n.d.).

\subsection{Introduction of Djenné}

Djenné (also Jenné), a historically and commercially important small city in the Niger Inland Delta of central Mali, was linked to the trans-Saharan gold trade. Inhabited since 250 B.C., Djenné is located on the internal delta of the Niger in Mali, at the crossroads of the major trade routes of West Africa (Gardi, Bernard, Pierre Maas, Geert Mommersteeg, et Bintou Sanankoua 1995). Beginning in the 13th century, Djenné developed as the distribution point for everyday commodities such as rice and corn and as a centre of arts, learning and religion. In the middle of the old city stands a great Sudanesestyle mosque (Fig. 2), built in 1220 and rebuilt in 1907 (Snelder 1984.). Djenné covers approximately 50 ha on the banks of the Bani River. It has an ethnically diverse population that increased from approximately 12,000 in

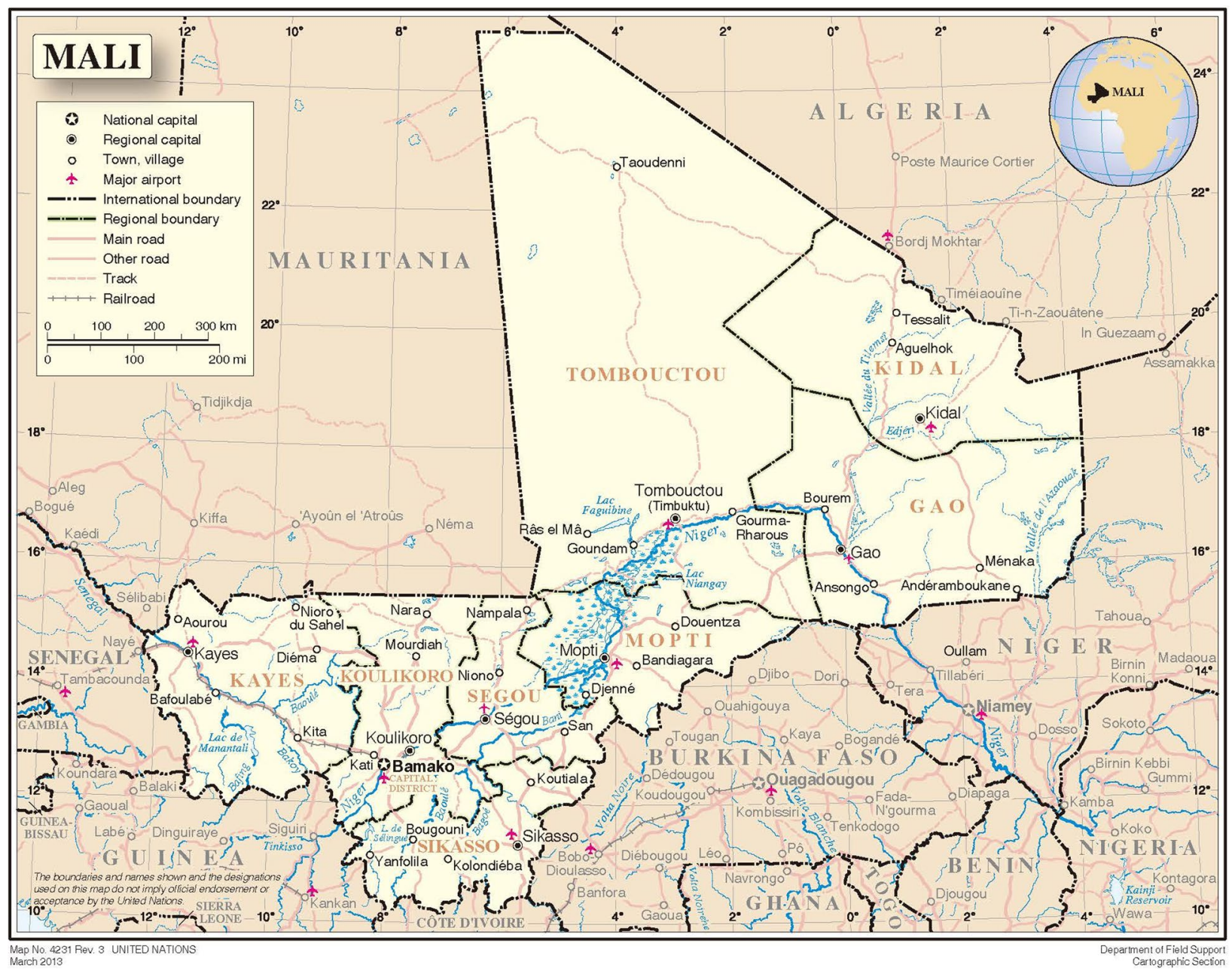

Fig. 1 Map of the Republic of Mali (Source: https://minusma.unmissions.org/sites/default/files/mali_map.pdf) 


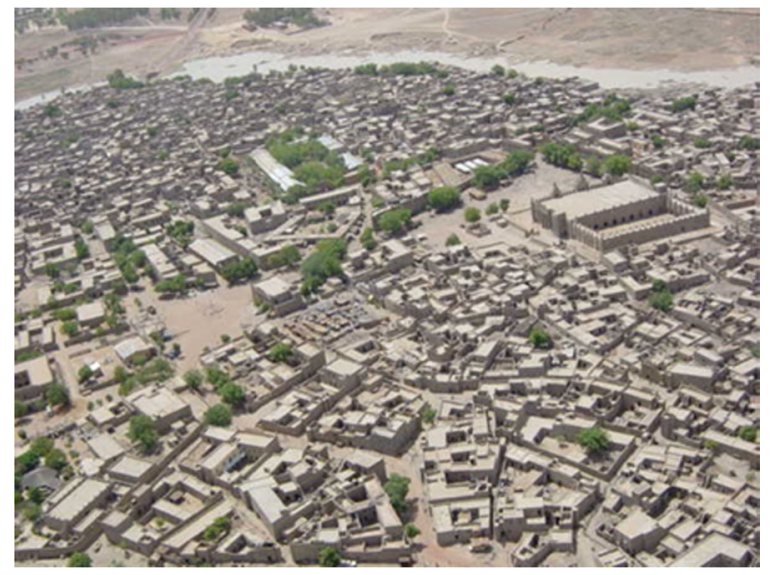

Fig. 2 Bird View of Djenné (By Helicpter), May 2004 (Source: the author)

1987 to 20,000 in 2007. It is famous for its earthen brick (adobe) architecture. The inhabitants of Djenné mostly speak Djenné Chiini, a variety of Songhay, but the languages spoken also reflect the diversity of the area. In the surrounding villages, Bozo, Fulfulde, and Bambara are also spoken.

Djenné, with its mosque, was added to the UNESCO World Heritage List along with the archaeology of Djenné-Jeno and the surrounding old towns of Hambarketolo, Tonomba, and Kaniana in 1988 (UNESCO World Heritage Centre, n.d.). Many restoration projects have been conducted by cultural agencies, nonprofit organisations and foreign government aid organisations. The restoration of the Great Mosque, which was started in 2008 by a foreign trust, provoked much discussion about cultural conservation and heritage preservation and shows the concern of the local population about its own heritage sites (AKTC 2012).

\subsection{Town organisation}

Djenné is organised around ethnic/professional quarters along a major axial system, at the centre of which the mosque and the market square form an imposing urban space (Fig. 3). Different ethnic groups coexist in the region and have different occupations and specialisations. The Bozo are fishermen, the Peulh (Fulani) raise cattle, the Bambara (Bamanan) are farmers, the Sarakolé (Soninke or Maraka) are merchants, and the Songhai (Sonrai) are Quran teachers or religious and traditional leaders. It is mostly the Bozo, the fishermen, who also provide the masons. This ethnic diversity is very clear on market days, when each guild has its own place (Fig. 4). Djenné offers spectacular scenery along the Bani River because of the distance



Fig. 3 The Great Mosque and market of Djenné, March 2004 (Source: the author)

between houses and the uniqueness of the buildings owing to the plastic quality of the earthen building material (Fig. 5). Indeed, the major construction material of the whole region is banco, the local name for the earthen construction material used in block conception as mortar for building plasters (Fig. 6).

\subsection{House typologies}

Three major typologies of city houses can be identified: Moroccan, Tukulor and Plain (Gardi, Bernard et al. 1995). These typologies relate to a certain extent to different historical periods and socioeconomic levels, but they refer specifically to how the main facade of a building is treated and how this treatment corresponds to the spatial organisation of the house (Joy 2008). Most houses are two-storey with roof terraces (Fig. 7). In all three house typologies, the spatial organisation reflects a strict separation of the sexes and the relative social positions of the inhabitants (Fig. 8). One aspect of the Sudanese-style house is the existence of the vestibule. The vestibule is a space used as an entrance hall located between the street and the courtyard or veranda. Usually, there is a door that can be opened and closed that connects to the courtyard, depending on how the inhabitant wishes to use it. In some cases, the vestibule is divided into two spaces, as is possible with the courtyard. In Djenné, the vestibule is used as a Qur'anic school space in most marabouts' (religious leaders') houses, as an atelier in artisans' houses, and as a meeting place in traditional chiefs' houses. It is therefore clear that the role of the vestibule depends mainly on the household head's social status and occupation. In the case of Djenné, it is difficult to say that 


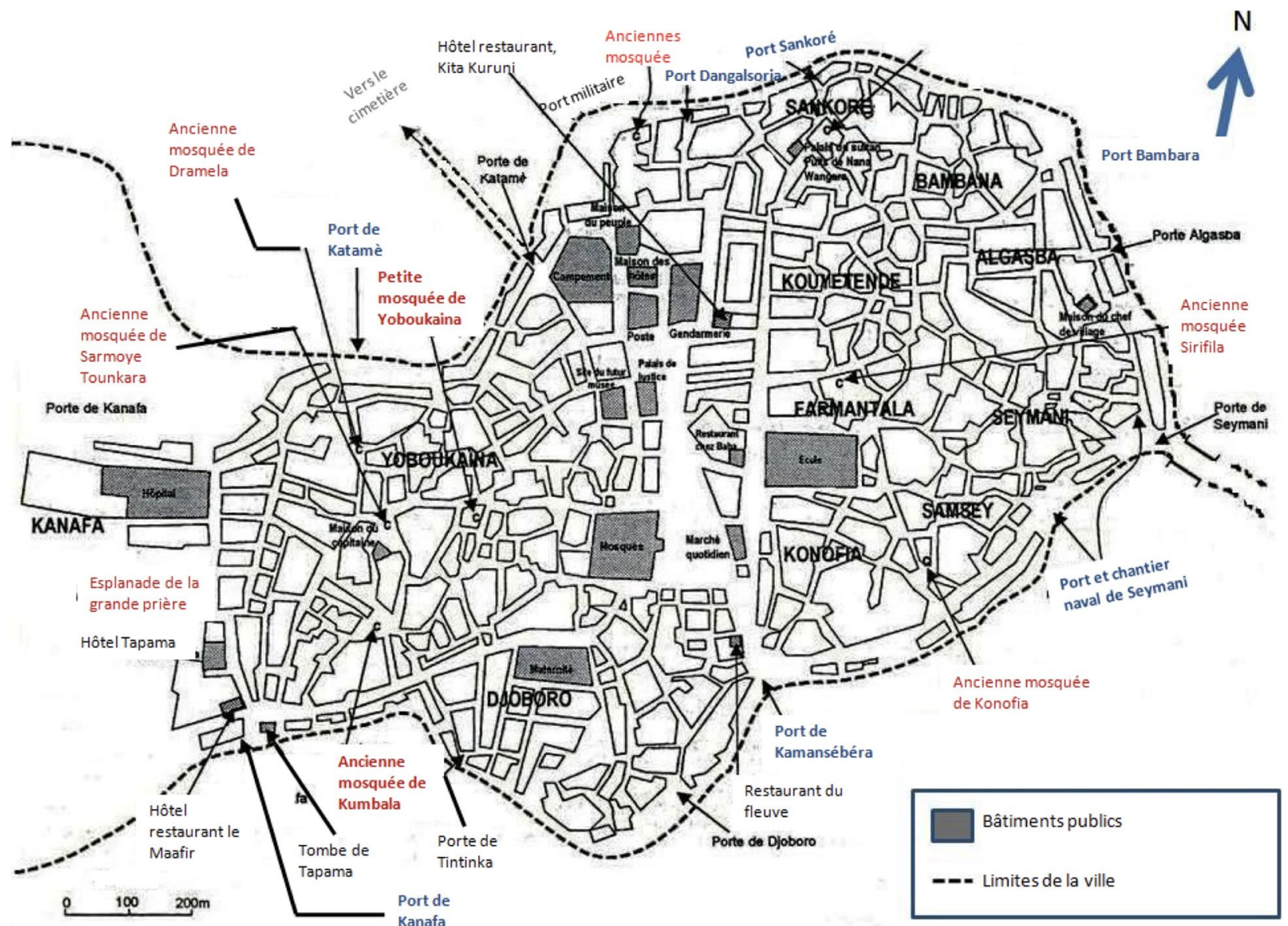

Fig. 4 Town of Djenné (Source: DNPC 2008)

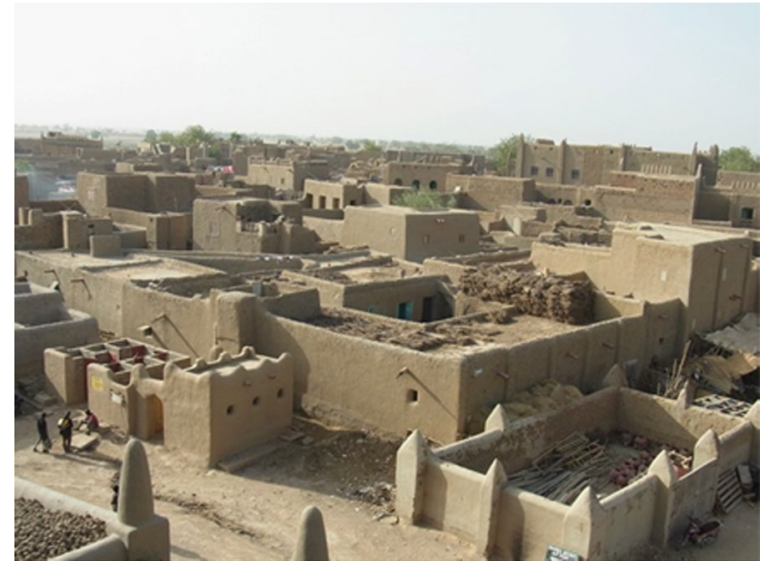

Fig. 5 Djenné's Townsscape, August 2011 (Source: the author)

the vestibule's role relates to a particular ethnic group or race. Nevertheless, it plays a very important role in socialising among different families in the community; therefore, it can be seen as a key to the cohabitation of different ethnic groups.

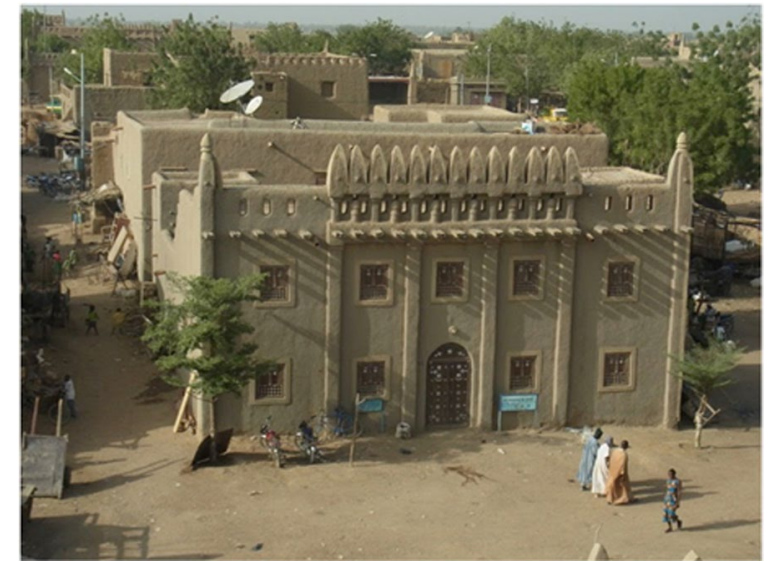

Fig. 6 Sudan architecture style of Djenné, August 2011 (Source: the author)

\subsection{Construction materials}

There are two types of earthen blocks. The older type, now no longer used except in specific restoration work, is called Djenné ferey (bricks or blocks of Djenné) and 

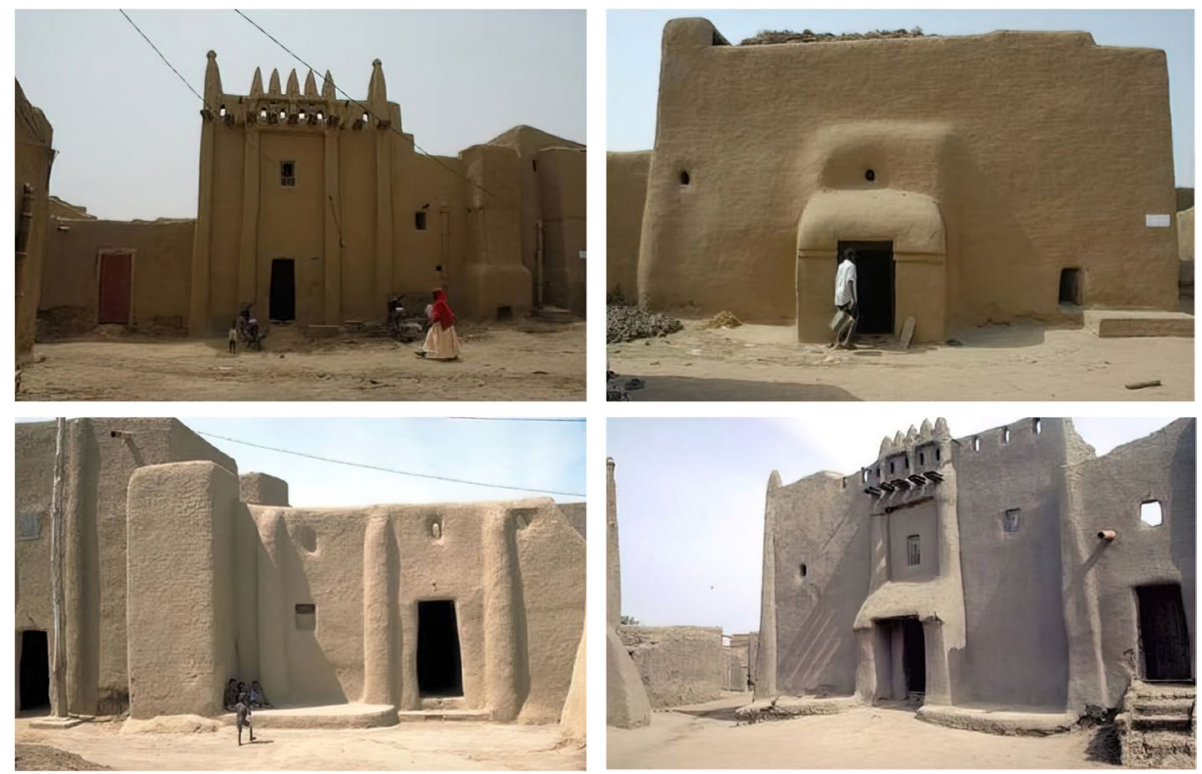

Fig. 7 The Different types of House Façade in Djenné, February 2010 (Source: the author)

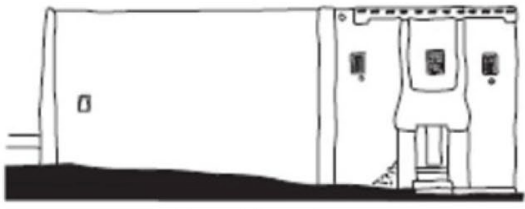

Front Elevation

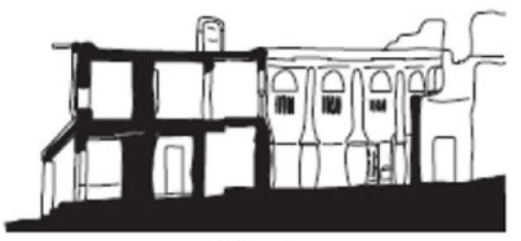

AA Section

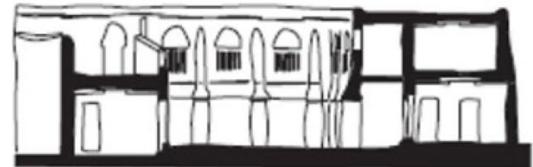

BB Section

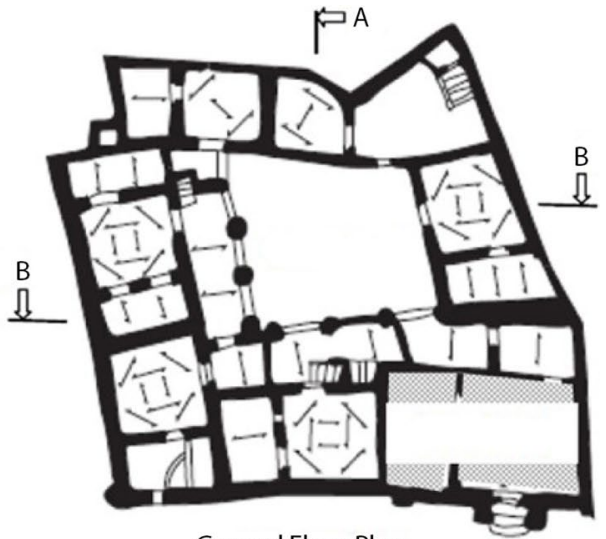

Ground Floor Plan
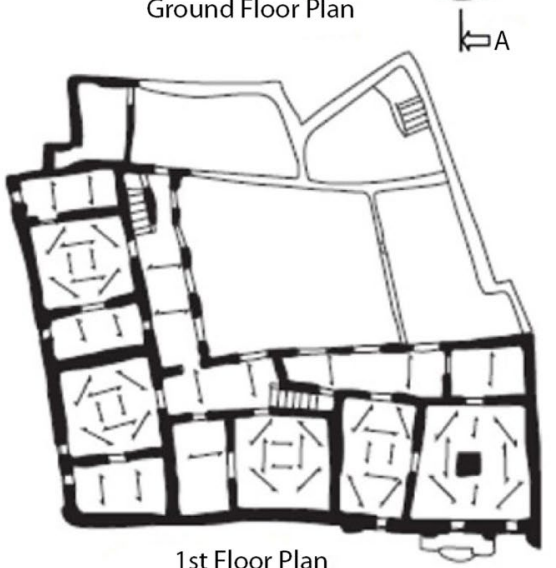

Fig. 8 House Plan of Djenné. Source: Plan de Conservation et de Gestion (Source: DNPC 2008, 48) 

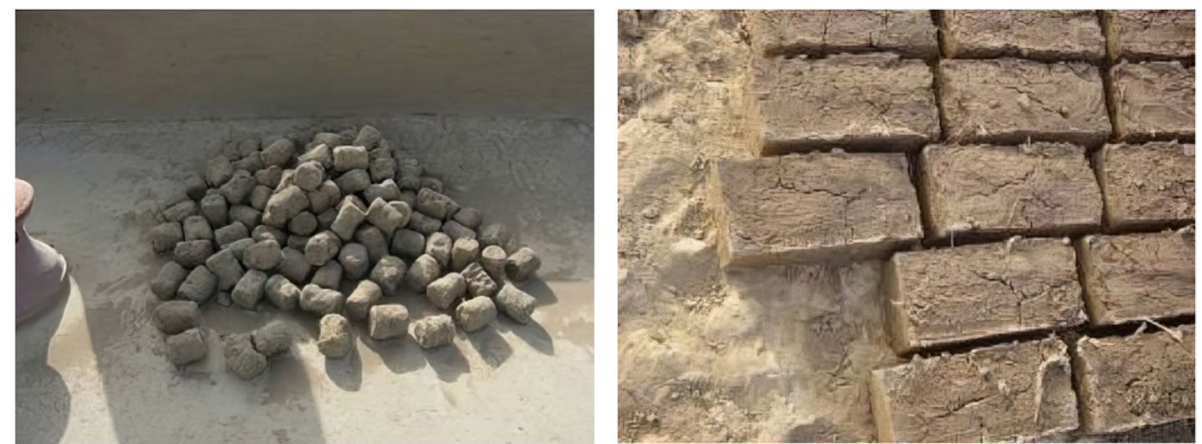

Fig. 9 Left: Old style mud bricks in Djenné (Djenné Ferey). Right: and new type of bricks (toubabou ferey). August 2009 (Source: the author)
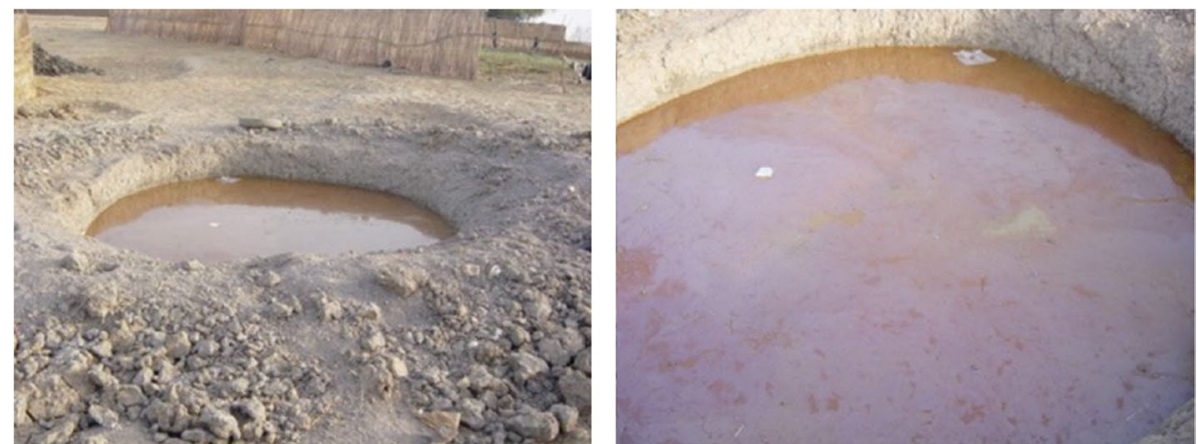

Fig. 10 Mortar Preparation in for house and buildings covering, March 2009 (Source: the author)

consists of roughly cylindrical pieces prepared manually by masons. Beginning in the 1930s, it became common to shape the earthen material into rectangular blocks form (toubabou ferey, or foreign blocks) (Fig. 9). During the dry season, masons transform the riverbanks into pits for the preparation of banco, the earthen material that forms construction blocks and rendering mortar, as previously explained (Fig. 10). The rendering mortar is made by mixing earth with rice husks, and the mixture is then covered with water and stirred occasionally, with the same quantity of rice husks being gradually added again. Other ingredients, such as baobab fruit powder, shea butter, and gum arabic (a type of glue), are also added. The mixture then rests for 2-3 weeks to ferment. Wood is used for the construction of floors, ceilings and roofs. It is also used e traditional masons (Brunet-Jaillred in the market.

\subsection{Mason Organisation (Barey-ton)}

In Djenné and Timbuctu, the construction process is a kind of family and community practice shaped by special ties that bind traditional masons (masons) and the families that own the houses (Fig. 11). A professional body, such as the barey-ton in Djenné, organises the traditional

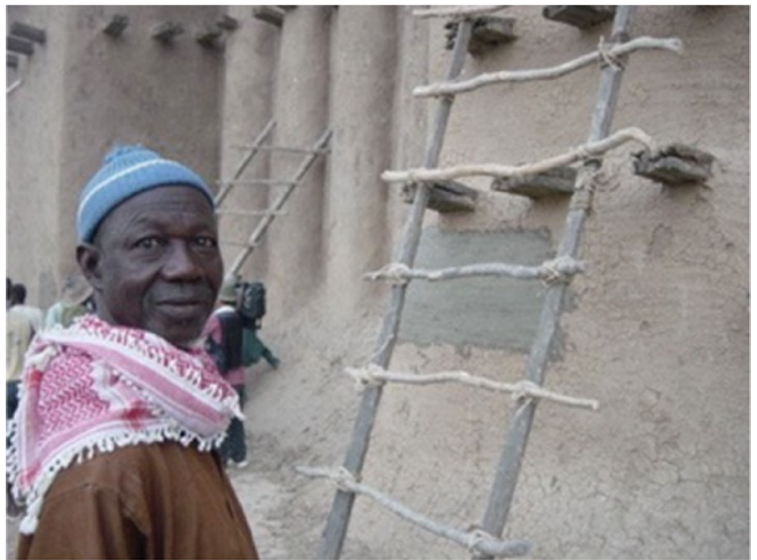

Fig. 11 The Chief Manson of Djenné, May 2004 (Source: the author)

masons (Brunet-Jailly 1999). Usually, if an individual is born into a mason family and is inspired by the métier, his apprenticeship begins at an early age. Traditional techniques and intangible practices play important roles as means of protection against professional risks. A family have "their mason" as much as the mason has "his family". The relationship extends from father to son on 
both sides (the son of the house owner's mason is the mason of the house owner's son) and lasts throughout their lives: the mason of the house also builds the house owner's grave. For a mason to work for a different client requires the agreement of both the family and his fellow masons. Masons (barey) are organised by a professional body, the barey-ton, which guarantees their professional training and establishes codes of conduct and support with other professions. Apprenticeship begins at around the age of seven. The apprentice undergoes a clearly codified structure of training, during the course of which he becomes familiar with the tools and materials, building techniques, building conception and supervision of construction until finally, in his midtwenties; he is officially accepted as a barey. Magic plays an important role, both as a means of protection against professional risks and as part of the code of relations between all participants in the creation of a house.

\section{Conservation projects in DJENNÉ}

\subsection{Overview of Djenné conservation projects}

Djenné has been subjected to many conservation and restoration projects since it was added to the UNESCO World Heritage List (Feilden and Jokilehto 1998) (Jokilehto 2011). These projects have been conducted by various national and foreign agencies, but few have truly involved local communities or the associated local masons as partners. The ownership of Djennés heritage, which the local communities wish to reclaim, has been ambiguous from the beginning of the conservation process. Some projects that are certainly necessary for Djennés population have been analysed scientifically and planned based on conservation theories that are not adapted to the historical and cultural knowledge of construction in Djenné (ICOMOS 1994). Here, I will provide an overview of a few projects and measures undertaken by international institutions to deal with conservation and rehabilitation or restoration in Djenné. (Table 1).

\subsubsection{House restoration projects by the Netherlands fund}

In 1995 and 1996, joint missions were created. The mission, acknowledging the special quality of the built space of Djenné, also recognised that if the city had not suffered serious aggression from "modernity", it was in part due to its isolation and the stagnation of economic activity, which at the same time were causes of the collapse of an alarming number of older structures (DNPC 2008). A short-term project was thus envisaged with the goal of "conserving this unique monument for the present and future generations", focusing on the rehabilitation of 168 monumental houses considered to be most representative of the "national cultural identity" of Djenné. The intervention ranged from minor repairs and wall rendering to total reconstruction based on existing documents or relying on oral tradition and the descriptions of those who remembered the original structures (DNPC 2008).

\subsubsection{Mosque restoration projects by the Aga khan Trust for Culture}

Beginning in 2004, under a public-private partnership, the Aga Khan Tthe centres of three cities in Mali. The AKTC started with the restitalise the centres of three cities in Mali. The AKTC started with the restoration of the Great Mosques of Djenné and Mopti and the Djingereyber Mosque in Timbuktu as well as public spaces around them (AKTC 2012). The mosque restorations became the most visible part of a multidisciplinary programme aimed at improving the quality of life in these cities (Fig. 12). These efforts included the installation of new water and sanitation systems, street paving, early childhood education, training, health care and economic development (Chabbi-Chemrouk 2007). The trust's work relies on close cooperation with local institutions and stakeholders and the participation of experienced local masons and specialists in restoration.

\subsubsection{State of conservation of architectural heritage in Djenné and actions}

In response to Decision 32 COM 7B.50 Ref. 23, the Republic of Mali (the State Party) submitted a state of conservation report on 22 March 2010 (World Heritage Committee 2010). This report provided information on progress achieved in the fields of management and conservation and particularly mentioned the following issues. It noted that properties continued to suffer changes with regard to their buildings essentially because of modifications of original house plans owing to new

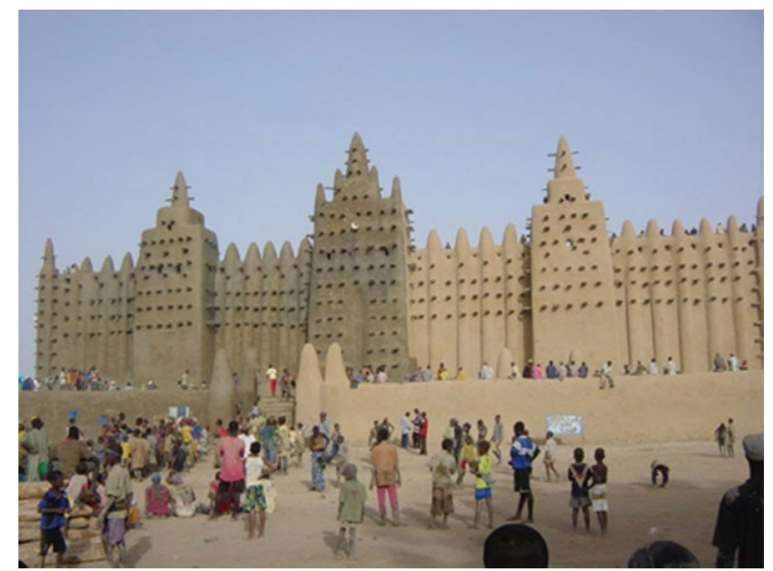

Fig. 12 Mosque recoring site by Djenné's inhabitants, May 2001 (Source: the author) 
Table 1 Conservation projects in Djenné

\begin{tabular}{|c|c|c|}
\hline Dates & Description & Partnership \\
\hline \multicolumn{3}{|c|}{ National Initiative Conservation Projects } \\
\hline 1996 & $\begin{array}{l}\text { Workshop and Training of West African's Cultural } \\
\text { Sites Managements }\end{array}$ & UNESCO Financial Support \\
\hline 1995 & $\begin{array}{l}\text { Survey about Tourism Impact on Cultural Sites } \\
\text { by } \\
\text { Cultural Mission Agencies of Djenné and } \\
\text { Bandiagara }\end{array}$ & UNESCO Financial Support \\
\hline 1993 & $\begin{array}{l}\text { Creation of Djenné Cultural Mission Agency by } \\
\text { Ministerial Decision ( } 93-203 \text { P-RM of } 1993 \text { June } \\
11 \text { th, } \\
\text { review by Ord. No. 01-032/P-RM of } 2001 \text { August } \\
\text { 3rd). }\end{array}$ & Malian Government \\
\hline 1988 & $\begin{array}{l}\text { Subscription of Djenné Cultural Heritage list on } \\
\text { the UNESCO World }\end{array}$ & $\begin{array}{l}\text { Malian Government } \\
\text { World Heritage Committee }\end{array}$ \\
\hline \multicolumn{3}{|c|}{ Djenné architectural conservation projects } \\
\hline $1996-2006$ & $\begin{array}{l}\text { Djenné's Architecture Restoration Project. } \\
\text { (Restoration of } 130 \text { Houses, Construction of New } \\
\text { Public Projects and valorised of Djenné's Masons } \\
\text { Know-How) }\end{array}$ & Funded by the Netherlands \\
\hline 1996 & $\begin{array}{l}\text { Rehabilitation of the inner city of Konofia, with } \\
\text { the support of young participants in the interna- } \\
\text { tional youth workshop }\end{array}$ & unknown \\
\hline $2008-2011$ & $\begin{array}{l}\text { Rehabilitation and revitalisation of the Youth } \\
\text { House }\end{array}$ & $\begin{array}{l}\text { Italian government Fund } \\
\text { (Supported by UNESCO, DNPC-Mission Culturelle, } \\
\text { CRAterre-ENSAG) }\end{array}$ \\
\hline 2008-2012 & Great Mosque renovation and Training & Aga Khan Trust for Culture \\
\hline \multicolumn{3}{|c|}{ Research and conservation projects for archaeological sites } \\
\hline 1998 & $\begin{array}{l}\text { Archaeological research project on the site } \\
\text { of the future museum and of the old colonial } \\
\text { dispensary }\end{array}$ & American Foundation named The Oliver Brunch \\
\hline 1998 & $\begin{array}{l}\text { Monitoring system for archaeological sites in the } \\
\text { vicinity of Djenné }\end{array}$ & Funded by the Netherlands \\
\hline 1996-1997 & $\begin{array}{l}\text { Safeguarding and development project of the } \\
\text { archaeological site of Djenné - Djéno }\end{array}$ & Funded by the World Monument Fund \\
\hline 1989-1994 & $\begin{array}{l}\text { Surveys of archaeological sites in the inner delta } \\
\text { of } \\
\text { Niger ("Togué Project") }\end{array}$ & $\begin{array}{l}\text { Institute of Human Sciences (ISH) of Mali and } \\
\text { Institute of Bioarcheology (BAI) of Groningen in } \\
\text { the Netherlands }\end{array}$ \\
\hline
\end{tabular}

Note: Based on the country report (Plan de Gestion de Djenné 2008-2012, tableau 4), revised by the author

needs for comfort and the increasing size of some family cells, the escalating costs of the materials involved in traditional livelihoods (rice and millet, baobab fruit, shea butter), the introduction of inappropriate solutions using cement and terra-cotta, the abandonment of numerous buildings that had fallen into ruin, and the appearance of new constructions in the inscribed periphery. In the face of these changes, the Cultural Mission of Djenné has questioned the contraveners and called for the cooperation of the municipal and administrative authorities. However, clearly, and according to the report, the support of these bodies has not yet been fully secured for the task of protection assigned to the Cultural Mission. The report also indicated efforts to collaborate with actors such as the association of masons (barey-ton), the Djenné Heritage Association (Association du Patrimoine de Djenné), the Association of Guides, the customary authorities and opinion leaders. Exemplary restoration was carried out in 2009-2010. The Djenné Mosque was also restored in the framework of a programme for the rehabilitation of earthen architecture established between the Mali Ministry of Culture and the AKTC (AKTC 2012). In the framework of the World Heritage Earthen Architecture Programme, a number of activities have also been implemented in Djenné since January 2010, including a project to rehabilitate the Youth House financed by the government of Italy and the preparation of town planning and construction regulations adapted 
Table 2 Numbers of analyses of strengths, weaknesses, threats and opportunities

\begin{tabular}{lllll}
\hline & Strengths & Weaknesses & Threats & Opportunities \\
\hline History, culture & 4 & 2 & 1 & 4 \\
Architecture & 5 & 12 & 6 & 4 \\
Archaeological sites & 2 & 2 & 3 & 3 \\
Juridic protection & 2 & 3 & 2 & 5 \\
Management and promotion & 2 & 4 & 2 & 3 \\
Crafts and tourism & 3 & - & & \\
\hline
\end{tabular}

to earthen architecture (Joffroy 2011). This project will enable the production of a technical guide.

Issues of cultural conservation and tourism development in the process of World Heritage preservation for the rehabilitation of earthen architecture also require the control of interventions at the property and in its buffer zone. The World Heritage Centre and the Advisory Bodies have noted the absence of clear working tools (town planning and construction regulations) to control the growth of new construction and prevent poor property rehabilitation despite the positive initiatives of the State Party (Varissou, Rakotomamonjy, and Eloundou Assomo 2006). As has been mentioned in previous reports, if these tools are not made available very soon, these changes will most certainly compromise the coherence of the urban fabric of Djenné. While applauding the support and intervention of the AKTC in the restoration of the Mosque, the World Heritage Centre and the Advisory Bodies would nevertheless welcome assurance that major restoration projects will be based on adequate documentation, a clear shared understanding of conservation approaches, and respect for traditional conservation practices. They also consider that all major projects should be tied to the management plan and respect its priorities. In 2002 and 2005, a commission to monitor Djenné submitted a report (World Heritage Centre missions; 2006: World Heritage Centre/ICOMOS/ICCROM Reactive Monitoring mission) that pointed out the following factors affecting the property: a) no management and conservation plan, b) pressure from urban development, c) deterioration of dwellings, d) waste disposal problems, and e) encroachment on archaeological sites. The 20082009 management and conservation plan prepared by the National Direction for Cultural Heritage was completed and submitted to the World Heritage Centre in October 2008 (DNPC 2008). This management plan aims to encourage the establishment of an integrated conservation and management system involving Djenné and the archaeological sites, promote local expertise and know-how in the field of conservation of earthen architecture, improve tourism and continue efforts to revitalise the ensemble of the ancient fabric. During the UNESCO meeting in Brasilia (Brazil, 25 July-3 August 2010), the World Heritage Committee reiterated its concerns about the absence of town planning tools and construction regulations in Djenné (World Heritage Committee 2010; Juma, 2010). It called on the international donor community to support actions to address or resolve sanitation problems in the ancient fabric. It also requested that the State Party submit the prepared town planning and construction regulations as well as clarifications on the boundaries of the property and its buffer zone, following the topographical survey of January 2008, to the World Heritage Centre by 1 December 2010 at the latest. It further requested that the State Party submit, by 1 February 2012, a report on the state of conservation of the property and progress achieved in resolving sanitation problems as well as the problems experienced at the archaeological sites for examination by the World Heritage Committee at its 36th session in 2012.

\subsubsection{Analysis of strengths, weaknesses, threats and opportunities}

The following analyses were performed based on documents consulted at the National Directorate of Cultural Heritage and the Cultural Mission of Djenné and information obtained from individuals who acted as resources (Table 2). They were then submitted to the stakeholders during the launch meeting of the management and conservation plan for the "Old Towns of Djenné", which was held on November 29, 2007, at the Maison du Peuple in Djenné (Chabbi-Chemrouk 2007).

\subsubsection{The evolution from action plan 2008-2012 to action plan 2018-2022}

The action plan submitted by the State Party for 2008-2012 had the following objectives, as mentioned before: (1) improve sanitation management in the city of Djenné, (2) redefine the boundaries of registered sites within the communities, (3) strengthen legal 
protections of sites within the new limits, (4) improve the state of conservation of the city of Djenné and the archaeological sites, (5) ensure better promotion of the sites for visiting audiences, and (6) promote the intangible cultural heritage (DNPC 2008). Today, Djenné is experiencing exponential urbanisation. Such rapid growth requires new actions for the new needs of the population. Demographic pressure induces a strong demand for territorial spaces for housing and other urban living amenities. The management and conservation plan for 2018-2022 was developed to respond to the major concern of conserving Djenné and its heritage in the difficult context of its history and had the following objectives: (1) review and update the urban planning diagram and establish sectoral urban planning for the city; (2) strengthen the legal protection of the site in the context of decentralisation and regionalisation; (3) undertake an emergency rescue programme for monumental architecture on threatened earth within the ancient fabric, and preserve and promote earthen architecture; (4) strengthen the protection of archaeological sites, improve their state of conservation and fight against loss and illicit trafficking; (5) carry out a wide-ranging awareness and information campaign in local communities on current cultural heritage and urban development issues (sensitise the populations, elected officials and stakeholders to heritage conservation, develop and implement a heritage education programme culture, and train and strengthen the professional capacities of heritage, craft and tourism stakeholders); and (6) safeguard elements of intangible cultural heritage (revitalise traditional knowledge and skills in craft fields, restructure Korans and respond to tourism stakeholders) (DNPC 2018).

\subsubsection{Issues raised and hope for the action plans}

Earthen architecture is one of the most powerful expressions of the human ability to create built environments from local resources. Recent research has confirmed the value of using earth as a building material. Natural disasters, social conflicts, industrialisation, the urban explosion and the globalisation of models and standards for the design and construction of housing are factors contributing to the disappearance of traditional knowledge and sociocultural practices linked to the construction and maintenance of earthen architecture (WHEAP 2011).

The effective implementation of the action plan requires the commitment and effective participation of the various partners to mobilise the necessary resources. Certainly, actions have been carried out and others are underway on the site, but much remains to be done to take the corrective measures needed to remove it from the List of World Heritage in Danger in the medium term. Despite the current context of residual insecurity, the Malian government, UNESCO and communities living on the site remain mobilised for the sustainable conservation of the site.

\subsection{Issues arising from projects}

In the case of Djenné, foreign agencies and experts lead preservation projects, and the local residents are mainly observers of what is supposed to be theirs. In some cases, new techniques were introduced to make mortars true, that some old techniques were revalorised. With its long construction tradition, the preservation and restoration project in Djenné seems to have created a gap between cultural conservation and preservation. This paper aims to provide an opportunity to rethink cultural conservation, which is lost in the preservation process.

\section{Issues raised by Djenné's conservation projects for the local communities}

\subsection{Issues raised from house restoration projects}

In the previous chapters, I mentioned the views of the government regarding house conservation projects. The reports mentioned that the conservation of Djenné as a living cultural heritage has been a success and that it helps to conserve and promote specific "know-how" on earthen architecture. From an economic point of view, Djenné was promoting itself as a centretruction and maintenance of earthen architecture(WHEAP of cultural tourism, which raised the prestige of "earth architecture". Some training and workshops in local construction techniques were held for young people. Efforts were made to collaborate with actors such as the association of masons (bareyton), the Djenné Heritage Association (Association Patrimoine de Djenné), the Association of Guides, the customary authorities and opinion leaders. However, the property continued to suffer changes with regard to its buildings. These changes were essentially due to modifications to the original plans of the houses and the escalating costs of materials used for traditional livelihoods (rice and millet, baobab fruit powder, shea butter). The introduction of inappropriate solutions using cement and other materials is quite popular, and the abandonment of numerous buildings that have fallen into ruin is increasing. The appearance of new construction in the inscribed periphery is quite frequent. 

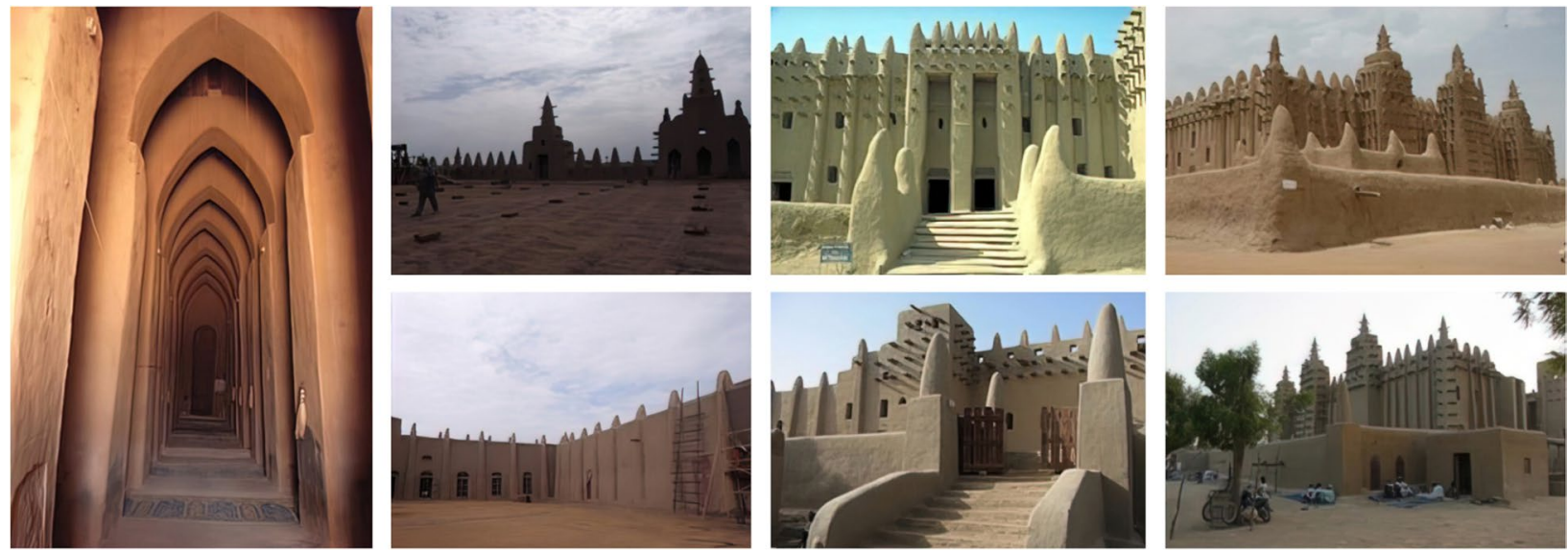

Fig. 13 Mosque conservation by Aga Khan Trust, before and after images, March 2011 (Source: the author)

\subsection{Issues arising from mosque restoration project}

In the conservation site reports and reviews, the Mosque restoration was said to have saved Djennés architecture, saved the national identity, which is based on architecture and construction, and given the population a sense of conservation (Fig. 13). The continuation of restoration and conservation projects will contribute to Djennés socioeconomic and tourism development.

On the other hand, the restoration projects raised certain issues, such as the gap between traditional and modern techniques or approaches during construction. The population mentioned that the AKTC had not kept its promise to provide material for the following years; there was some confusion between conservation techniques and systems and traditional methods of preservation. However, in the case of the Djenné Mosque, the populations began to be much unified and took responsibility for their own cultural heritage conservation as they raised issues concerning the Mosque project by AKTC.

\subsection{Issues related to town shape and construction material problems}

Recently, new constructions in concrete and cement blocks at the entry of Djenné have become popular (Fig. 14). One explanation is that this part of the site is not included in the conserved area. These buildings belong mostly to successful Djenné residents who live in the capital city, Bamako, and are building second houses. The use of new material and techniques can be discussed, but the design of those buildings does not reflect the essence of Djenné's architecture or building shapes. This means a lack of control in preserving construction systems by local and central government bodies. In the conserved area, almost 700 houses, including 4 municipal buildings, have been recovered by fired clay (Brunet-Jailly 1999). The lack of using the essence of Djennés housing plan or construction spirit should be pointed out. The local group Djenné Patrimoine conducted research on new conservation and building Techniques, and the Djenné Patrimoine conservation group said that conservation in a culturally evaluative context is needed in the town (Brunet-Jailly and Scherrer 2017).

\subsection{Post-Malian north region crisis in Djenné and the deterioration of tourism}

Today, life in Djenné is supported by rice farming, fishing, and livestock farming in the surrounding

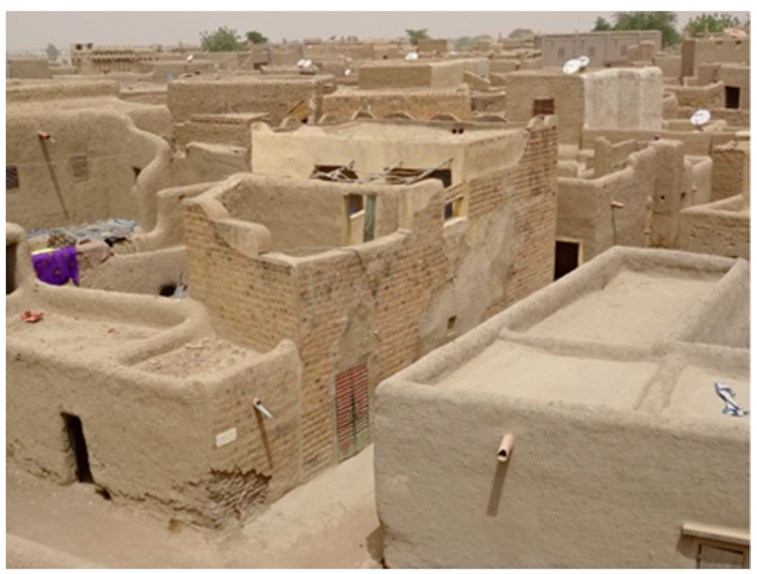

Fig. 14 Town Shape with new construction, March 2015 (Source: the author) 
floodplains, but these livelihoods are also in crisis due to drought. Tourism has compensated for this crisis in recent years, as Djenné was one of the most visited tourist sites in Mali. Nearly 50 tourists visited Djenné every day during the peak of tourism. Therefore, there were 5 hotels, 5 restaurants, large and small shops, and souvenir shops. There were more than a dozen guides for tourists. However, the principal hotel infrastructure in Djenné (Campement - Maafir - Chez Baba - Résidence Tapama, Kita Kuru, Djenné - Djeno, Hotel Welingara) shows that the number of tourists decreased between 2003 and 2007 and after 2012 due to the rebellion in northern Mali and the series of foreign kidnappings by several groups of bandits in the same area (Diakite Siriman and Wang 2021).

However, tourism is now in a state of destruction due to the intensification of the Sahara conflict, which became an independence movement in northern Mali. During my recent visit to Segou, Djenné and Mopti, I saw many empty hotels, guesthouses, restaurants, and bars. With no tourists, all of those who worked in hotels, restaurants, tourist guiding businesses and souvenir shops are unemployed. Tourism was seemingly the main business in those regions for local and young populations. Some government-supported hotels have a few foreign guests and public workers for seminars, but most of them have closed. Guides and young people I have known for many years lost their jobs; many have probably moved to the capital, Bamako, and some to neighbouring countries to continue to work in the same jobs. Some have returned to their villages. Tourist facilities are suffering the same problem because people do not feel a need to maintain them, and many buildings have collapsed (Fig. 15). Regardless of how extensive the tourist business was, people are losing the courage to conserve their own heritage designated as World Heritage. We should return to the question of for whom World Heritage should be preserved.

\section{The importance of tangible knowledge and the role of masons (Barey) in reviving Djenné}

The main problem observed in Djenné is that the unique style of earthen architecture is in the process of collapse unless it can be regularly restored. Yearly house repair or recovery is quite expensive for normal Djenné residents. If tourism flourished again in Djenné, the number of residents with the capacity to restore their houses will increase because they consider their houses part of the tourist attraction. On the other hand, the earthen houses in Djenné were constructed by specialised masons, or barey, as mentioned before. Djenné's earthen architecture masons are well known even in neighbouring towns. These masons are trained by a strict apprenticeship process and form a closed artisan union and community.
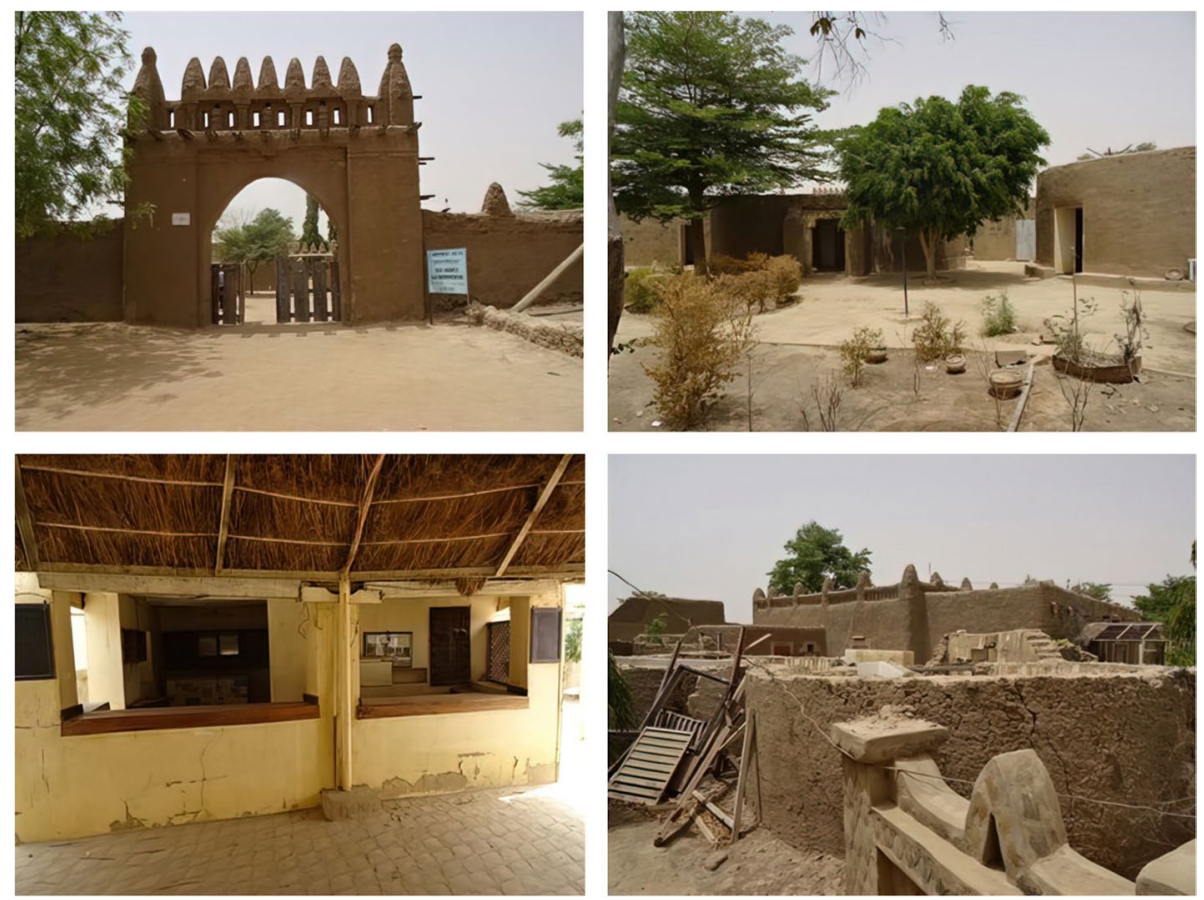

Fig. 15 Tourist Facilities in ruins, March 2015 (Source: the author) 
The highly complex and sophisticated earthen houses in Djenné have been created by barey, traditional masons. This work requires not only complex building techniques but also magical rituals. These rituals are handed down in the apprenticeship process, but ftestimony of three masons in Djenne and the master barey sometimes prefers to take the magical "secrets" to his death rather than teach them to apprentices if they are not sufficiently qualified. The value of Djenné as a World Heritage Site lies not only in the Sudanesestyle Great Mosque but also in the architectural culture of the entire city. To maintain and conserve Djenné's earthen architecture, the full involvement and participation of traditional mason groups and the barey-ton are indispensable.

\subsection{Involvement in Djenné masons' Association in the Process of conservation}

The author has been conducting fieldwork, including a wide range of interviews with Djenné's masons, since 1995. The author also conducted an observation participation survey about house spaces, inhabitant behaviours and residents' consciousness of the vestibule and courtyard. During those research projects, the focus was on the understanding and meaning of space structured by the masons as well as by the inhabitants. The results have been reported in different scientific journals.

The investigation of the masons began with an understanding of their social status in Djenné, their origin if it was specific to a particular ethnic group (in Djenné, many mason families belong to the Bozo ethnic group) and the meaning of their association, the barey-ton. I also asked about the etymological meaning of their social attribute, barey (in the dialect spoken in Djenné, Djenné Chiini). The series of interviews led me to understand the importance of the mason, or barey, in Djennés social structure as well as the strong relation between the construction process and the masons' intangible relation to sites and land. When the author conducted research and coordinated a film documentary on the entire process of Mosque recovery in 2008, the mixed practice of animism and Islam was also strongly present at Djenné's construction site. There was also some spiritual meaning in the process of preparing the earthen mortar for plastering. The masons' association as a social structure was quite new compared to their history and was founded mainly to organise their work status. However, the barey-ton can also be considered a secret society because the masons do not share their know-how even among themselves. During my research, they underwent a crisis for many years due to the generation gap and the process of participating in conservation projects supported by foreign institutions. In conclusion, Djenné's earthen architecture is not only a technical result of a construction activity but also a range of sociocultural activities, which should be part of the World Heritage Site. The role of the mason needs to be well understood before any further analysis on the conservation of Djenné's earthen architecture can be performed.

\subsection{The testimony of three masons in Djenné and their view of earthen architecture}

This paragraph reports a series of interview surveys conducted with traditional masons in Djenné. Here, I introduce 3 of them: Béré Yonou, the elder of Djenné's masons; Nouhoum Toure, an educated mason; and Sese, a dynamic mason involved in recent projects.

The main contents of the interviews are as follows:

(1)Environment while growing up.

(2) Reason for becoming a mason.

(3) How to pass down the "architectural secrets" possessed by the master to the disciples.

(4) Precautions when building earthen architecture.

(5)Expected future role of earthen architecture building activities and intangible culture.

(6) Thoughts about the modernisation of sites such as Djenné in World Heritage.

In addition, they talked about what kind of rituals were performed, taking as examples the building, restoration, and conservation projects that each of them had been engaged in. However, the masons felt that this information should be suppressed to the point of being taboo in conversations with others. Therefore, although there was a limit to what I was allowed to hear, I would like to express my gratitude for being able to describe anything about this issue. All the interviews were conducted between 2015 and 2017.

\subsubsection{Béré Yonou}

(born in Djenné, 84 years old, Bozo ethnic group, 4 wives and 10 children)

People refer to Béré Yonou (Fig. 16) as the master of Djenné ferey, the traditional cylindrical blocks of Djenné.

(1)Environment while growing up and reasons for becoming a mason.

Béré Yonou is a descendant of Ousmane Yonou and Soumaila Yonou, the leading masons of Djenné (and the only one who inherited the tradition from the family). He became an apprentice to his father at the age of 6 (mainly as a brick carrier). The earthen architecture masonry work is basically inherited from his father, but in the Djenné style, an apprentice does not always become a disciple. From 1950, he began to learn the work of earthen architecture in earnest. He lost his father at the age of 15 and became a disciple of his father's younger 


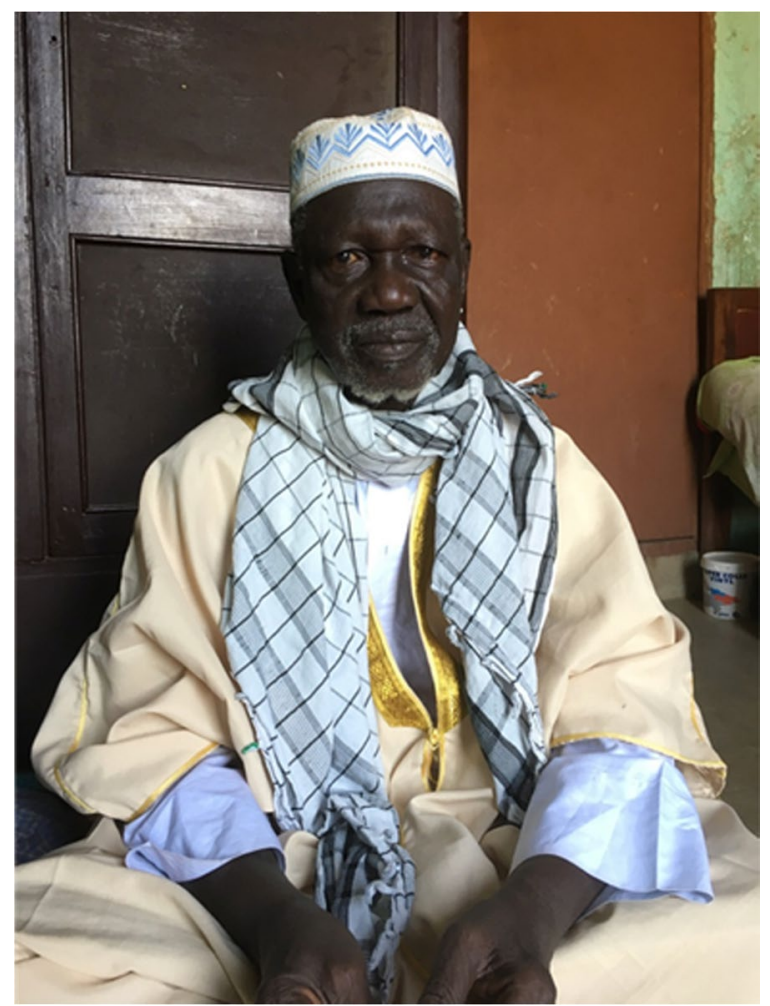

Fig. 16 Béré Yonou, March 2017 (Source: the author)

brother. He became independent in 1979, and since then, he has been responsible for numerous buildings using the Djenné ferey.

(2)Precautions when building earthen architecture.

When deciding on the space composition, it is important to measure the site with your own feet. After confirming the condition of the site, perform the necessary ceremonies, offerings and cultic practices. To confirm the power of the land, I try to tap it by hand and check the sound. When starting a construction, first, lay bricks at the four corners of the site. When laying bricks in each corner, recite the necessary prayers. More than seven types of grain are needed to make the foundation, and the details are the secret of each mason. Construction begins after a series of rituals and offerings.

(3)Knowledge and techniques of earthen architecture.

In the field work, how to carry earthen mortar, how to pass bricks (back or front), how to make foundations, how to stack bricks (how to raise walls), how to assemble roofs, and how to paint walls (earthen material and cutting) will be taught in order as techniques. For a disciple to become a full-fledged mason, I have six conditions that must be met: intelligence, obedience, career advancement, respect, support, and baraka (the blessings, force).

(4)Transmission of "architectural secrets" to disciples.
The architectural secret of the mason is entrusted to the disciple who is his first disciple or the disciple who follows him most. It is good for the person who has the secret to tell the disciples and offspring as needed, but it is forbidden to let it flow (tell it) sideways. If there is no suitable person, it may not be possible to tell anyone.

\subsection{Nouhoum Toure, called Bocoum}

(born in Douanza, 63years old, Songhai ethnic group, 3 wives and 8 children)

Nouhoum Toure's (Fig. 17) father is a native of Djenné, but after a family conflict, he was forced to migrate. $\mathrm{He}$ learned more about the work and secrets documented in the record (Tariq) that his father left behind.

(1)Environment while growing up and reasons for becoming a mason.

Nouhoum Toure was born in Douanza, north of Mopti, some distance from Djenné. At the age of 6 , he returned to his father's hometown of Djenné with his father (Ali Toure (Baba)). Prior to leaving Djenné, his father had worked in a group of seven masons to restore the Great Mosque at the time. All of those group members temporarily left Djenné and moved to Bandiagara and Douanza in the Dogon Mountains. His father died in Djenné in 1961, but the other six were scattered. His father kept

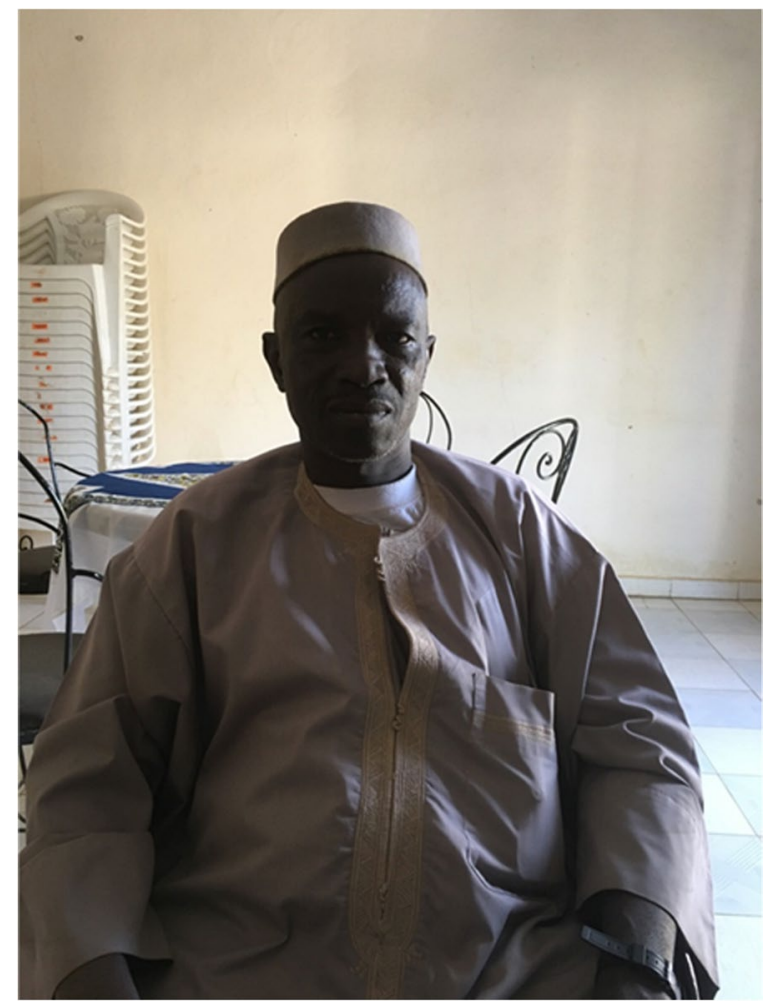

Fig. 17 Nouhoum Toure, March 2017 (Source: the author) 
secrets in his Tariq of the restoration of the mosque as well as the secrets of the process.

(2) Precautions when building earthen architecture.

His grandfather Issa Toure was a slave merchant as well as an earthen architecture mason. His great-grandfather, Ibrahima Toure, was an intellectual who emigrated to Djenné from Goundam, north of the Niger River Delta. Before that, his ancestors (Moussa Toure) seem to have been engaged in the development of Djenné, which consisted of seven islands.

Knowledge of earthen architecture was mostly learned from his father, but at the apprenticeship stage, it was common for him to leave his father and work as an apprentice for his brothers or cousins. When he became independent in 1972, the daily salary of a mason ranged from $200 \mathrm{Fr}$. CFA to $600 \mathrm{Fr}$. CFA. He says that he learned the manners and human formation of masonry using the record (Tariq) left by his father. The process of studying adobe architecture is the same as the process of becoming a full-fledged man. Building a house can destroy something, so be sure to perform the necessary rituals and prayers at the right time.

(3)Knowledge and techniques of earthen architecture.

There is invisible and dangerous competition among earthen architecture masons (masons), and how to swing and protect is important (for example, in the middle of a site, for an unknown cause, the wall may come off or even fall down). For him, the most important aspect of construction is how to mix earthen material and how to ferment it (Labou Kore in the local Djenné Chiini dialect). How to make the foundation (rice, grain (two types), charcoal, cotton seeds, treasure shell) is also important. Seven types of earthen material (Labou) are used in construction at different levels: Labou bibi (black), Labou chiri (red), Labou Korendi, Labou couscous, Djamaye Labou (banco for pottery), Labou Kora (yellow), and Labou do (banco which contains sand). It is necessary to thoroughly understand the role of each one.

(4)Transmission of "architectural secrets" to disciples.

Before work, you need to do Tinyeda (soil fortune-telling), fix the start date, and then repeat sacrifices (offerings) on the 2nd, 12th, 17th, 22nd and 27th of every month (lunar calendar). I also try to suspend on-site work on the 27th and the last Wednesday. You can transfer all knowledge and secrets to the disciple you trust most, chosen by observation.

\subsection{Mafoune Dienepo (commonly known as Sésé)}

(born in Djenné, 57 years old, Bozo ethnic group, 2 wives and 12 children)

Mafoune Dienepo (Fig. 18) is the main mason of the Maison de Djenné Patrimoine, he said he learned the metier from his mother's family.

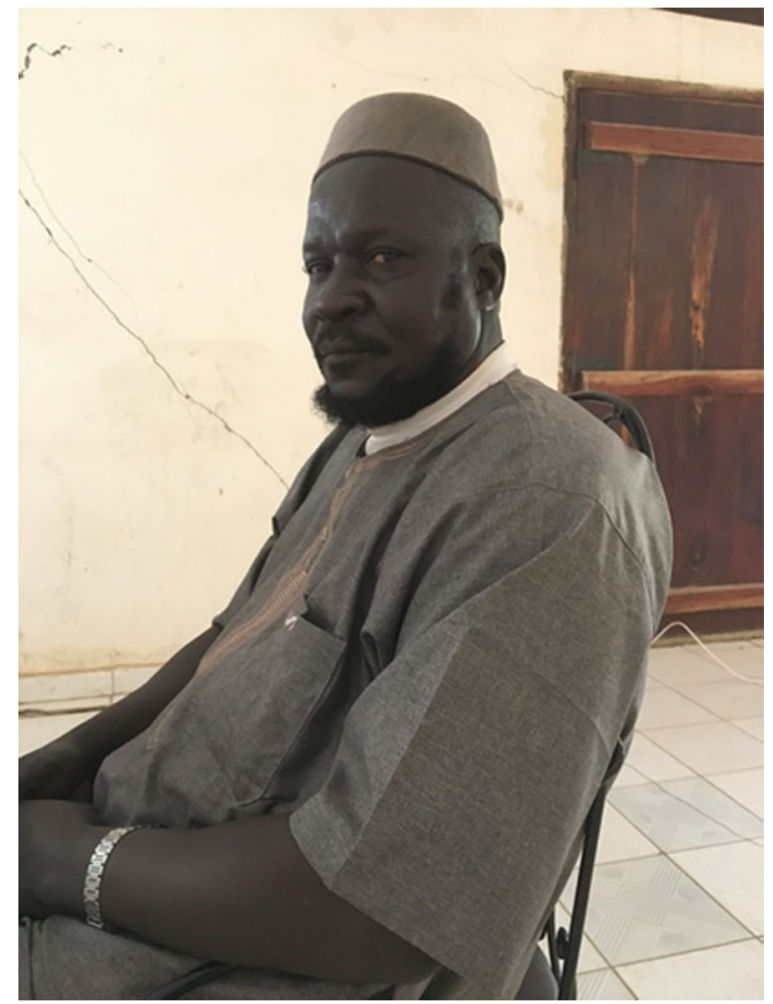

Fig. 18 Mafoune Dienepo, March 2017 (Source: the author)

(1)Environment while growing up and reason for becoming a mason.

An ancestor (Tassey Nassire) moved from Dandy in northern Mali with a Maiga family (a religious Songhai family that immigrated to Djenné as Qur'anic school teachers and leaders) as an exclusive mason of the Djenné village chief, also from a Maiga family. Tassey had twins who became the most capable masons in Djenné, and one of the twins was Sésé's grandfather.

His mother's grandfather, was also a mason, as was the wife of Saoudatou Nassire's father, Tassey Nassire. Her name was Saby Dienepo. The wife's brother was Sésé's grandfather, who was called Dandy Barey Laindy, which means a descendant of the chief mason from Dandy. His father, Mahamane Dienepo, taught his eldest son the work of a mason but not Sésé, the child of his first wife. There were 13 brothers. Sésé first became a disciple of his distant cousin, who had learned from his father. At that time, four of his brothers were masons. After studying with his cousin, he became a disciple of his father.

After becoming independent, he moved to the area around Mopti. He believed that earthen construction community members can broaden their knowledge and enhance their brotherhood by learning from various masters. 
(2)Precautions when building earthen architecture.

First, it is necessary to thoroughly analyse the site. Sacrifice sheep before work, and sprinkle their blood on the premises. Since each site is different, you must always perform some kind of ritual or offering. If there is a Djin (spirit) on the site, a Dagua (earthen pot) may be prepared. When you are feeling sick or unmotivated during on-site work, you may think that there is something wrong and make offerings. Grains, cotton and kola nuts are essential to the foundation. How to lay bricks and pray when laying them are also important.

(3)Knowledge and techniques of earthen architecture.

Before starting the site, it is important to always lay three bricks in each of the four corners. If the site is old, try to get permission and advice from those who have worked before you.

(4)Transmission of "architectural secrets" to disciples.

Observe the disciples to whom you may wish to transfer the knowledge. The attitude of the person and enthusiasm for the work are important. Your child and your other disciples must not be in a competitive relationship. If there is no one to tell, it is possible to die with the secrets and knowledge. In addition, there are times when a dream tells you whom to pass the information on to.

\subsection{Summary of the interviews}

All three masons admitted that some kind of ritual is needed on the site. The route to becoming an earthen architecture mason in Djenné is not a clear hereditary system. In addition, there are multiple routes to learning, so it is necessary to perform a more advanced analysis. The mason's work or métier consists of technique and magic (cultic). The ritual has a strong magical element, but when listening to recordings of the prayers used during the rituals, Allah and the Prophet Mohamed are mentioned, and Islam and animism are mixed (Fig. 19).

The problem with the teacher-apprentice system is that there is no guarantee that an individual will be able to learn the magical part, even if he acquires the skills. In recent years, there has been a divergence between young (sometimes trained at school) and old (strictly traditional) mason in the Djenné masons' association (bareyton: 150 members). Determining the real reasons for this divergence and generation gap requires in-depth analysis in future research.

\section{Conclusion}

The question of why Djenné is being preserved, for whom and for how long into the future needs to be addressed on a number of levels. If the town is being preserved exclusively for its residents in order to ensure the protection of their "identity" - a nebulous term that would refer to knowledge transmission, cultural pride or continuity - then an adaptation of the local architecture may help residents to meet the demands of the upkeep of their homes and fulfil a desire for better housing conditions and modernisation (Figs. 20 and 21).

For people who were lucky enough to have their houses restored, the benefits were primarily functional. Further difficulties came from people's view of the restoration project as an opportunity to improve their homes. Furthermore, the use of fired clay tiles on
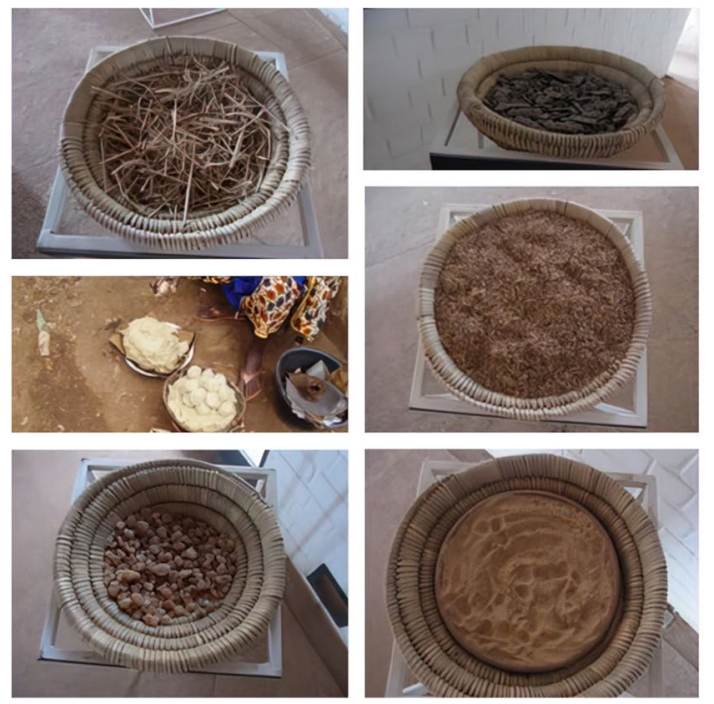

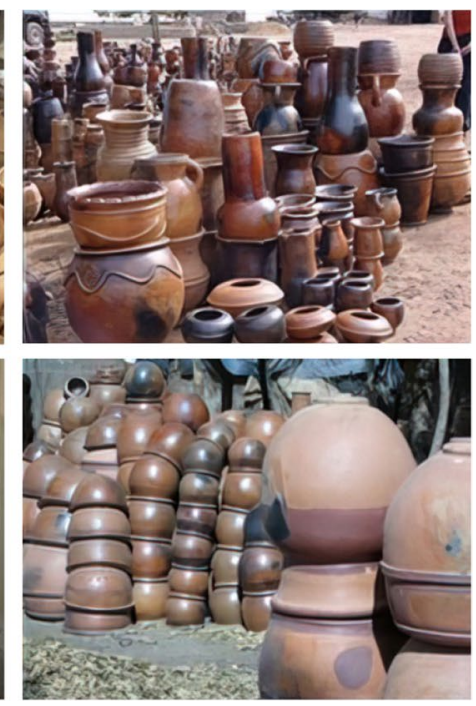

Fig. 19 Ingredients used for mortar and offerings for site preparation, March 2011, Mopti, Djenné (Source: the author) 

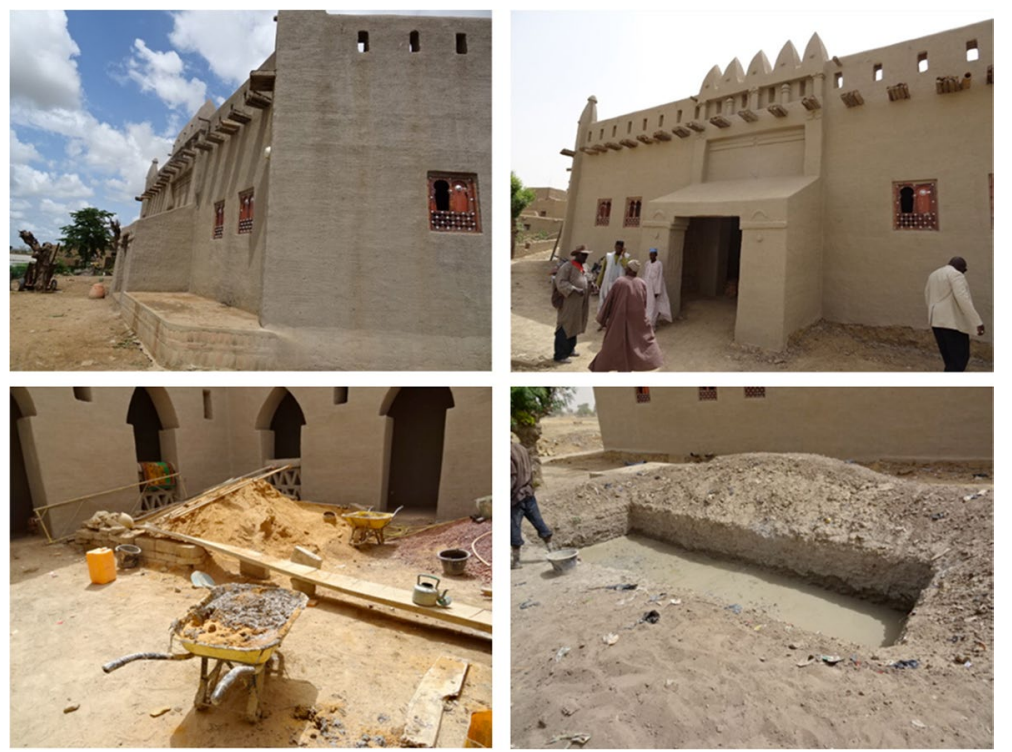

Fig. 20 Maison du Patrimoine de Djenné (Patrimoine House by ACCROTERRE), September 2015 (Source: the author)

houses to protect them from rain, a practice condemned by UNESCO but seen as a potential solution by Djenné residents, is described functionally rather than aesthetically. In the case of Djenné, therefore, housing is simultaneously a basic human need and right-the right to shelter-but is also considered World Heritage and falls under new thinking about cultural rights and identity. The UNESCO website introduces Djenné as a "fascinating city of Earthen Architecture". However, for many residents of Djenné, the current earthen construction and housing are considered cramped living conditions. The walls must be plastered frequently, which is becoming expensive.

What is contradictory in this process is that when imposing rules for cultural heritage protection, the basic human right to shelter and freedom from constant anxiety about it should be given more weight than the protection of World Heritage.

With the help of foreign organisations, more than 100 traditional Djenné houses have been restored. Project officials reported that the residents were satisfied and more aware of the preservation of earthen architecture.

When many tourists visited Djenné, it was thought that maintaining traditional houses would have an economic impact, but due to the sharp decrease in tourists, it became difficult to maintain that idea.

Additionally, for the residents of Djenné, both the tangible part and the intangible part are important for the protection of their architectural heritages, but the intangible culture part has been excluded from the target in most restoration projects thus far.
In preserving culture, the local community should set goals for preservation endogenously and carry out architectural actions rooted in the community (Van Uytsel and Jurčys 2012).

Another important issue for Djenné is that the water supply system is being improved without sufficient sewage facilities, and wastewater overflows into the streets. There is no domestic waste treatment system. To protect the world cultural heritage of Djenné, it is also necessary to improve the livelihoods of these local residents.

\section{Future projects for Djenné as an earthen architecture showcase}

Concerning the preservation of earthen architecture, Djenné, in the time of abundant tourism, received many projects from foreign institutions, such as the European Union (EU) and other foreign government agencies and institutions. These institutions constructed 4 model projects: the Heritage House of Djenné (Maison du Patrimoine) (2014-2015) by ACROTERRE and Djenné Patrimoine; the Djenné Museum (2013-2014) by the European Union; the House of Craftsmen of Djenné (2014) by the Kingdom of Denmark; and the Djenné manuscripts library (2007) by European Community Funds, USAID and the US Embassy, with manuscript conservation activities supported by the British Library. Since their delivery, the 4 projects in earthen architecture, whose construction was sometimes contested-for example, because the Djenné Museum by a Malian architect was 


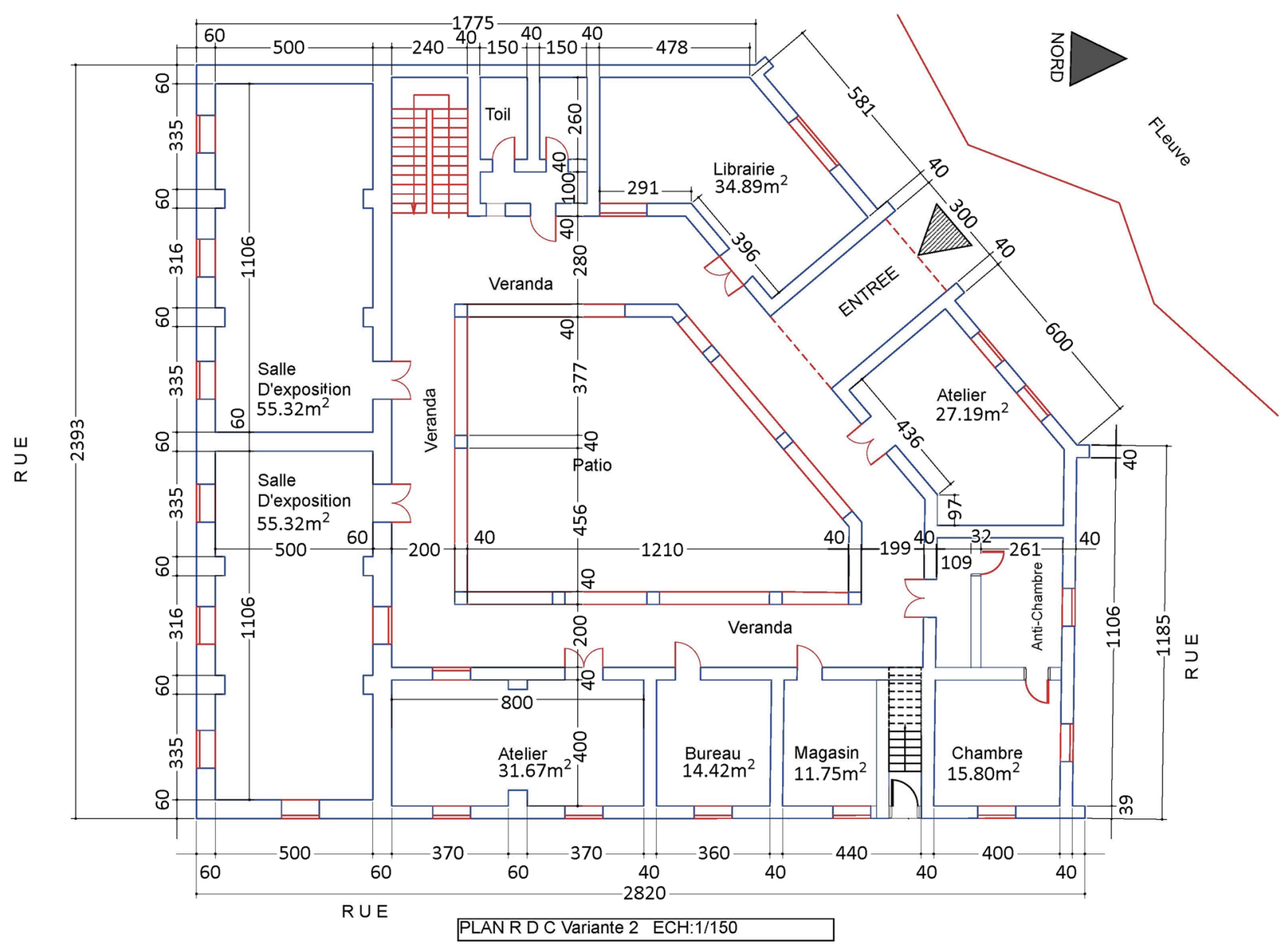

Fig. 21 Maison du Patrimoine de Djenné (Patrimoine House by ACCROTERRE), September 2015 (Source: Olivier Scherrer)

in concrete blocks covered by earthen mortar-have become nonfunctional, with the exception of the manuscripts library.

However, situated in the centre within walking distance of each other, these four facilities have the potential to awaken excitement, to motivate, to encourage or to stimulate local people to become involved in the conservation process (Fig. 22). It is quite possible to educate the local community about the importance of their earthen architecture, the material, and their heritage and to involve them in the conservation process. This work can be done mainly by the Djenné Patrimoine Association and supported by foreign experts in the field. Each of the four buildings has its own characteristics, and they comprise a basic facility for inheriting Djenné culture, such as earthen architecture, art, crafts and oral culture.

Such value must be recognised by local populations to encourage their involvement in the conservation process. However, instead, by being listed as a World Heritage Site, the local people recognised the value of socioeconomic and tourism development. The town became a tourist attraction, and currently, the people have been abandoned by the tourism industry. Now, for future generations, it is important for the local community to rethink its identity in the anthropological context.

The value of Djenné as a World Heritage Site lies not only in the Sudanese-style Great Mosque but also in the architectural culture of the entire city. Visiting the four facilities on an axis in walking distance, with the Great Mosque of Djenné alongside, provides more opportunities for people to gain the courage to conserve their own town, designated as World Heritage. The Heritage House of Djenné (1) could showcase for younger and future generations the experience of local masons in their traditional techniques and tangible methods. Young people could learn many things that they do not learn in school. Such knowledge would contribute to reducing the gaps between traditional masons and the young generation for their apprenticeship in Djenné. The House of Craftsmen of Djenné (2) would have a collection of craftwork 


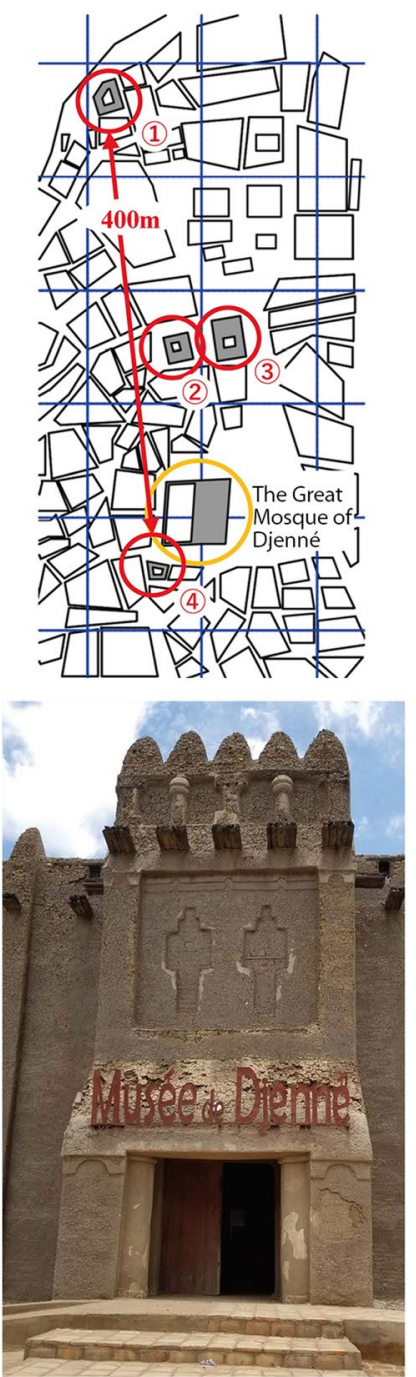

(3) the Djenné Museum

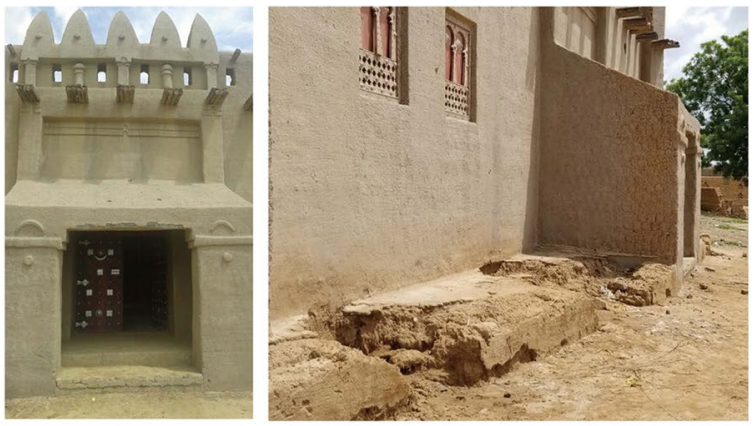

(1) the Heritage House of Djenné

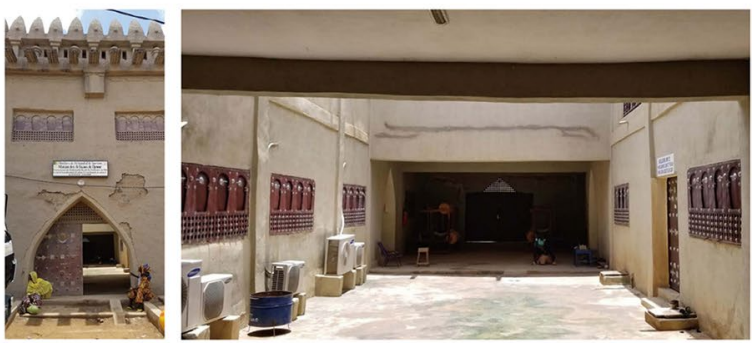

(2) House of craftsmen of Djenné

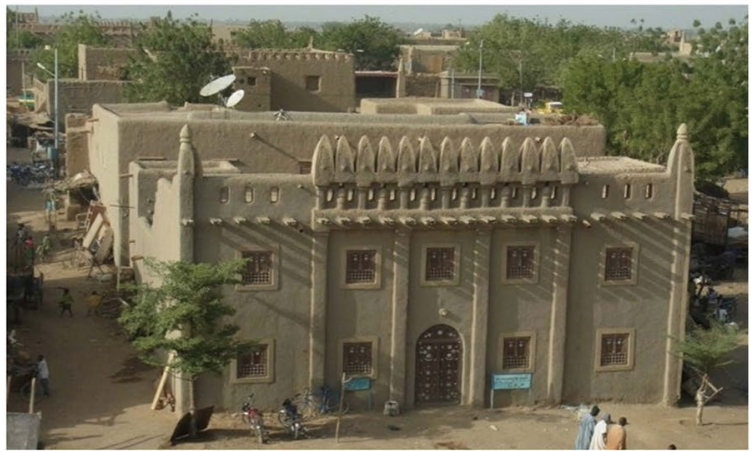

(4) Djenné manuscripts library

Fig. 22 Future Project of Djenné, April 2021 (Source: Tomoko Kono, and the author)

in the vestibules and entrance halls of their houses. The Djenné Museum (3) emphasises arts and culture regardless of their commercial value to tourists, but these values can help people rethink their identity and propose solutions for conservation. Furthermore, they would be able to learn more from the ancient documents in the Djenné manuscripts library (4).

These four facilities could provide content for the involvement of the local people in the conservation process as their own project rather than as observers of others' projects. They can then rethink conservation in the cultural evaluative context of the town.

This project, called a "Community Pride Axis", is a development of a pedestrian network and should be considered for Djenné's future.
Acknowledgements

Not applicable.

\section{Author's contributions}

The author read and approved the final manuscript.

\section{Funding}

Not applicable.

Availability of data and materials Not applicable.

\section{Declarations}

\section{Consent for publication}

Written informed consents have been obtained from Béré Yonou, Nouhoum Toure, Mafoune Dienepo, and the Chief Manson of Djenné.

\section{Competing interests}

The author declare that they have no competing interests. 
Received: 10 May 2021 Accepted: 14 October 2021

Published online: 30 December 2021

\section{References}

AKTC (Aga Khan Trust for Culture). 2012. Mali: Earthen Architecture Programme Presentation, website, Geneva: AKTC https://www.akdn.org/akdn/akdn/ ms/where-we-work/west-africa/mali/cultural-development/mali-earth ern-architecture-programme. Accessed 4 May 2021.

Brunet-Jailly, Joseph. 1999. Djenné: D'hier à demain. Bamako: Edition Donniya. Brunet-Jailly, Joseph, and Olivier Scherrer. 2017. Protecting architectural heritage in Djenné: A civil society point of view. J African Cultural Heritage Studies 1 (1): 72-94.

Chabbi-Chemrouk, Naïma .2007. 2007 on site report review: Conservation of Djenné, Djenné: Djenné municipal office http://ghn.globalheritagefund. com/uploads/documents/document_1192.pdf, Accessed 4 May 2021.

DNPC (Direction Nationale du Patrimoine Culturel du Mali). 2008. Plan de Conservation et de Gestion des «Villes anciennes de Djenné» - Mali. 2008-2012 (préparé par Klessigué Sanogo, Directeur National du Patrimoine Culturel, et Yamoussa Fané, La Mission Culturelle de Djenné, avec le soutien du Fonds du Patrimoine Mondial et le Bureau Multi-pays UNESCO à Bamako), Bamako: Ministère de la culture du Mali. https://whc.unesco. org/en/documents/102566, Accessed 10 May 2021.

DNPC (Direction Nationale du Patrimoine Culturel). 2018. Villes anciennes de Djenné. Plan de Gestion et de Conservation: 2018-2022.

Feilden, Bernard M., and Jukka Jokilehto. 1998. Management guidelines for world cultural heritage sites. Rome: ICCROM.

Gardi, Bernard, Pierre Maas, Geert Mommersteeg, Koninklijk Instituut voor de Tropen, Museum für Völkerkunde und Schweizerisches Museum für Volkskunde Basel, and Musée national du Mali. 1995. Djenné, il ya cent ans, Amsterdam: KIT Publications.

ICOMOS. 1994. The Nara document of authenticity (https://www.icomos.org/ charters/nara-e.pdf, lastly viewed on may 4, 2021), Charenton-le-Pont: ICOMOS.

Joffroy, Thierry. 2011. Réhabilitation et revitalisation de la Maison des jeunes, rapport final du projet financé par le Gouvernement Italien dans le cadre de WHEAP (Programme Architecture de terre du Patrimoine Mondial) et Centre du patrimoine mondial de I'UNESCO réalisé en partenariat avec la Mission Culturelle de Djenné, Villefontaine, CRAterre-ENSAG.

Jokilehto, Jukka. 2011. A history of architectural conservation. New York: Routledge.

Joy, Charlotte Louise. 2008. Enchanting Town of Mud: The Politics of Heritage in Djenné, a UNESCO World Heritage site in Mali, PhD Thesis submitted for University College London.

Juma, Muhammad. 2010. Rapport de mission: Villes anciennes de Dienné-Mali, Mission du 26 juin au 06 juillet 2010, Rome: La Cooperazione allo Sviluppo, Ministero degli Affari Esteri https://whc.unesco.org/uploads/activ ities/documents/activity-21-16.pdf, Accessed 4 May 2021

Siriman, Diakite, and Yanan Wang. 2021. The survival of earthen architecture in Malian Sahel, case study: The Historic City of Djenné. Current Urban Studies 2021 (9): 83-106.

Snelder, Raoul. The Great Mosque at Djenné: Its Impact Today as a Model 1984. https://jstor.org/stable/10.2307/al.ch.document.sip200048. Accessed 10 May 2021.

UNESCO, World Heritage Centre, About Mali World Heritage https://whc. unesco.org/en/statesparties/ml/ (last visited 14/11/2021)

UNESCO World Heritage Centre. Mali: Properties inscribed on the World Heritage List. https://whc.unesco.org/en/statesparties/ml. Accessed 14 November 2021

Van Uytsel, Steven, and Paulius Jurčys. 2012. 'Heritage and societies: Toward the 20th anniversary of the Nara document and beyond' conference report. Journal of Japanese Law 34: 309-316.

Varissou, Souayibou, Bakonirina Rakotomamonjy, and Lazare Eloundou Assomo. 2006. Mali, les Villes Anciennes de Djenné (Site du patrimoine Mondial, BIEN: C 116 rev., Année 1988, Critères iii \& iv), Mission de suivi réactif 13-17 Mars 2006, Bamako: ICOMOS, World Heritage Committee, and ICROM. https://whc.unesco.org/archive/2006/mis116rev-mar06.pdf. Accessed 4 May 2021.

WHEAP (World Heritage Earthen Architecture Programme). 2011. Values of Earthen Architecture: Achievements 2010-2011, Project Progress Report,
Paris: UNESCO. https://whc.unesco.org/document/107099. Accessed 4 May 2021.

World Heritage Committee. 2010 . Agenda for the Thirty-Fourth Session (Brasillia Brazil) https://whc.unesco.org/archive/2010/whc10-34com-7B.Adde.pdf. Accessed 4 May 2021.

\section{Publisher's Note}

Springer Nature remains neutral with regard to jurisdictional claims in published maps and institutional affiliations.

\section{Submit your manuscript to a SpringerOpen ${ }^{\circ}$ journal and benefit from:}

- Convenient online submission

- Rigorous peer review

- Open access: articles freely available online

- High visibility within the field

- Retaining the copyright to your article

Submit your next manuscript at $\boldsymbol{\nabla}$ springeropen.com 